\title{
Research Hotspots and Trends of Domestic Corporate Social Responsibility-Visualization Analysis of Knowledge Map Based on CNKI and Citespace V
}

\author{
Guanlai Huang \\ School of Business Administration, South China University of Technology, Guangzhou, China \\ Email: glhuang_scut@163.com
}

How to cite this paper: Huang, G.L. (2018) Research Hotspots and Trends of Domestic Corporate Social Responsibility-Visualization Analysis of Knowledge Map Based on CNKI and Citespace V. Open Journal of Business and Management, 6, 797-811.

https://doi.org/10.4236/ojbm.2018.64060

Received: August 1, 2018

Accepted: August 27, 2018

Published: August 30, 2018

Copyright $\odot 2018$ by author and Scientific Research Publishing Inc. This work is licensed under the Creative Commons Attribution International License (CC BY 4.0).

http://creativecommons.org/licenses/by/4.0/

\section{Open Access}

\begin{abstract}
This paper was based on a total of 3873 studies on corporate social responsibility which were included in China National Knowledge Infrastructure (CNKI) from 2008 to 2017 as data source, using the latest version of Citespace software to analyse the author and co-author network, the institutional co-authored network, and the keywords co-existing network in the field of domestic corporate social responsibility and displayed in the form of knowledge map, aiming at analyzing the research hotspot and frontier trends of domestic corporate social responsibility. The results show that: First, the hotspot and frontier of domestic corporate social responsibility research can be summarized as stakeholders, financial performance, political relevance and social responsibility information disclosure; Second, the network structure of the authors and agencies in domestic corporate social responsibility is loosely structured; the relationship is not close enough and the cooperation degree is low, which restricts the research progress of domestic corporate social responsibility. Through the analysis of the knowledge map in the field of domestic corporate social responsibility, it will provide valuable reference for future research in this field.
\end{abstract}

\section{Keywords}

Corporate Social Responsibility, Knowledge Map, Bibliometric

\section{Introduction}

As early as 1930s, American scholar Sheldon started the research of Corporate Social Responsibility (CSR). In the work of The Philosophy of Management, the 
concept of corporate social responsibility was put forward; it believes that corporate social responsibility is not only for maximizing profits, but also for moral considerations. Social benefits are much higher than corporate profits. Davis holds that corporate social responsibility refers to decisions and actions of businessmen that at least partially exceed the direct economic or technological interests of the business [1]. With the development of reform and opening up and the development of the socialist market economy, the research on corporate social responsibility in the domestic academic circles began to rise and flourished. In recent years, the incident of "one hundred and seventy thousand flat rice seeping pit" in Hebei, the Apple Corp "sweatshop" event and the "explosion" event in Tianjin port have not only caused great public opinion in the community, but also brought the research of corporate social responsibility to the climax in the academic circle. Youli and Wang Jinshun believe that corporate social responsibility is the legal and moral responsibility that enterprises must undertake for their own and social development. On the one hand, enterprises need to create profits to ensure the integrity and continuous appreciation of state-owned assets and to provide more employment opportunities for the community. On the other hand, enterprises need to be responsible for all their actions and their consequences [2]. Recently, Alibaba founder Ma Yun in Hangzhou 2017 Yunqi conference also said that if Alibaba has gone, he hopes to leave three things to the world: First, there should be a research institute leaving the technology left; Second is to establish a lakeside university to leave the business wisdom; Third is to establish a public welfare foundation and leave behind social responsibility. We can see that the research of corporate social responsibility has a very important social value. After nearly 50 years of development, China has made a wealth of academic research achievements in corporate social responsibility; in the case of increasing number of documents, interdisciplinary integration of multidisciplinary and the continuous enrichment of research methods, simply combing and summarizing the theoretical deduction and qualitative research of previous research results, the conclusions are not only incomplete, but also inevitably have subjective randomness. The traditional methods of literature review are no longer applicable. In order to overcome these defects and deepen the understanding of this field, more and more scholars have used the knowledge mapping method of scientific literature to study it. This method has become the mainstream of literature measurement in the field of management and economics [3].

On the basis of systematic integration of the research literature on corporate social responsibility, this paper uses quantitative analysis and visualization software Citespace V to analyze the co-author network, organization network and key word co existing network in the field of domestic enterprises social responsibility, then display it in the form of visual knowledge map. Trying to sum up the hot topics in the field of corporate social responsibility, further reveals the development trend of corporate social responsibility research in China, with a 
view to providing reference and reference for future research.

\section{Data Sources and Methods}

\subsection{Data Sources}

The research data used in this paper come from the general library of academic journal online publication of CNKI. After entering the database, using CNKI's advanced retrieval function, the retrieval condition of thematic words is "corporate social responsibility", with a time span of 2008-2017 years. The selection of source categories is SCI source journal, EI source journal, core journal and CSSCI. The retrieval date is November 6, 2017. After the retrieval, a total of 4075 documents were obtained, and 3873 valuable research samples were finally obtained after removing the non academic papers, such as the inspiration of the draft, the conference review, the news report, the interview of the characters, and the papers that had nothing to do with the subject of the study; exporting the basic information of the documents in Refworks format, such as titles, authors, units, abstracts and keywords and so on, naming the exported files according to the requirements of the visualization software Citespace, and finally using the data conversion function of the software to complete the conversion of the data.

\subsection{Bibliometric Method}

This paper uses Citespace V, the latest version of information visualization software developed by Professor Chen Chaomei who is the Lifetime Professor of Drexel University and lecture of Yangtze River scholar at Dalian University of Technology, and his team to visualize the collected data. Citespace is a Java application for analysis and visualization of co citation networks, whose main goal is to help analyze the emerging trends in the knowledge domain, to detect and visualize the fundamental changes in science disciplines [4]. Citespace provides a cooperative network analysis of the author, organization or country, and provides a co-occurrence analysis of topics, keywords or WoS classifications, as well as the analysis of the co citation of the literature, the co citation of the authors and the co citation of the periodicals. Users can adjust the parameters such as threshold, font size and so on to achieve the best display effect.

\section{Data Analysis and Results}

\subsection{Analysis on the Research Force of Domestic CSR}

\subsubsection{Core Author Analysis}

Researchers are the backbone of academic development and play a vital role. Run Citespace V software and select "1998-2016" in the parameter setting time span. The slice span of each time is 1 years. The node type selects "Author" (keyword), and Top $\mathrm{N}=50$ only preserves the first 50 core authors in each time slice, setting the appropriate threshold, selecting the "Minimum Spanning Tree" algorithm to simplify the co existing network and then obtaining the co existing network of 494 nodes and 182 links. Table 1 lists the core author in the domestic 
corporate social responsibility literature. From this, we can known that the top of the list is Tian Hong (eighteen) from the Jilin University School of business, Zhou Zucheng (seventeen) from the Shanghai Jiao Tong University school of economic and management, Xin Jie (seventeen) from the Shandong University school of management, and Xiao Hongjun (seventeen) from the Chinese Academy of Social Sciences institute of industrial economics. They constitute the backbone of the research in the field of domestic corporate social responsibility, which have an important impact on the research in this field, but there are more nodes in the network but fewer connections and the cooperative network density of the authors is only 0.0015 . It shows that the degree of cooperation among the domestic enterprise social responsibility researchers is low, the network structure is relatively scattered and has not formed a certain scale, which will affect the research on the social responsibility of domestic enterprises to a certain extent.

\subsubsection{Core Organization Analysis}

To analyze the research institutions in the field of social responsibility in domestic enterprises, we can find out the core forces to promote the research in this field from the institutional level, and help the researchers to find the benchmarks and the gap [3]. Running Citespace V software, in addition to the node type to select "Institution", the rest of the parameter settings are consistent with the front, and obtain a common network containing 381 nodes and 162 links. Table 2 lists the top ten research institutions in the domestic corporate social

Table 1. The core author in the domestic corporate social responsibility literature.

\begin{tabular}{ccc}
\hline No. & Name & Research institution \\
\hline 1 & Tian Hong & Jilin University, School of Business \\
2 & Zhou Zucheng & Shanghai Jiao Tong University, School of Economic and Management \\
3 & Xin Jie & Shandong University, School of Management \\
4 & Xiao Hongjun & Chinese Academy of Social Sciences, Institute of Industrial Economics \\
\hline
\end{tabular}

Data source: self organize.

Table 2. The top 10 institutions in the domestic corporate social responsibility literature.

\begin{tabular}{|c|c|c|c|}
\hline No. & Issuing agency & Institutional attributes & $\begin{array}{c}\text { Document } \\
\text { quantity }\end{array}$ \\
\hline 1 & Business School, Renmin University of China & Double first-rate & 52 \\
\hline 2 & School of Antai Economy and Management, Shanghai Jiao Tong University & Double first-rate & 49 \\
\hline 3 & College of Accounting, Zhongnan University of Economics and Law & University of first class discipline construction & 45 \\
\hline 4 & School of Managemen, Huazhong University of Science and Technology & Double first-rate & 42 \\
\hline 5 & Management School, Jinan University & University of first class discipline construction & 41 \\
\hline 6 & School of Management, Shandong University & Double first-rate & 39 \\
\hline 7 & School of Economics and Management, Southwest Jiao Tong University & University of first class discipline construction & 37 \\
\hline 8 & Business School, Central South University & Double first-rate & 36 \\
\hline 9 & School of Economics and Management, Beijing Jiaotong University & University of first class discipline construction & 27 \\
\hline 10 & College of Accounting, Southwestern University of Finance and Economics & University of first class discipline construction & 27 \\
\hline
\end{tabular}

Data source: self organize. 
responsibility literature. They form the core strength of research institutions in the field of domestic corporate social responsibility. We found that the institutions with higher dispatch were mainly distributed in the first tier cities, such as north guangguang and some second tier cities, and most of them were listed in the national double first class construction list. This is mainly because the number of enterprises in the first or second line cities is large and the sense of social responsibility is generally strong. It provides a large amount of material for the local scientific research institutions, and the selection of the first class list also provides more resources for the research institutions. Although the organization has cooperation but the network density is still low, only 0.0022 , the network organization has not formed a certain scale, which has affected the research progress of domestic enterprise social responsibility to a certain extent.

\subsection{Analysis of the Forefront of Domestic CSR Research}

\subsubsection{Hot Cluster Analysis of Domestic CSR Research}

The key words in literature usually extract and generalize the core content of the whole article. The analysis of the co-occurrence relationship and its intensity of key words in a research field can help us to identify the research hotspots and frontiers in this field [4]. Run Citespace V software, except the node type is changed to select "Keyword", the remaining parameters are consistent with the previous ones. Since the retrieval of literature is based on "corporate social responsibility", the highest frequency of the key word "corporate social responsibility" is hidden in order to get the best results of the knowledge atlas. Then get the knowledge map of domestic corporate social responsibility keywords. On this basis, according to the co-occurrence relationship between keywords and their intensity, used LLR clustering algorithm to cluster, finally get the domestic corporate social responsibility keywords LLR clustering knowledge map. Combining frequency and Silhouette value used to measure the internal homogeneity of clusters [4], five main clusters are selected (see Table 3). These clusters have high frequency and high internal homogeneity, so they can reflect the hot spot of CSR research in China.

Table 3. Keywords main clustering of domestic CSR.

\begin{tabular}{ccccl}
\hline No. & Cluster naming & Frequency & Silhouette & Cluster members \\
\hline 1 & Stakeholder & 253 & 0.717 & Strategy; financial performance; corporate social performance \\
2 & $\begin{array}{c}\text { Information disclosure } \\
\text { of social responsibility }\end{array}$ & 19 & 0.786 & $\begin{array}{l}\text { Corporate governance; institutional environment; legitimacy; } \\
\text { social responsibility report certification }\end{array}$ \\
6 & Political connection & 20 & 0.853 & $\begin{array}{l}\text { Corporate social responsibility performance; institutional pressure; } \\
\text { performance demands; social capital }\end{array}$ \\
7 & Private enterprise & 49 & 0.762 & Sustainable development; circular economy; value creation \\
8 & Sa8000 & 17 & 0.881 & Enterprise competitiveness; labor standards; scientific outlook on development \\
\hline
\end{tabular}

Data source: self organize. 


\subsubsection{Research Hotspots Evolution Timezone Knowledge Map Analysis of Domestic CSR}

Through the analysis of the knowledge map and related literature, the socialresponsibility of domestic enterprises can be divided into two stages in the last ten years: the first stage is 2008-2012 years and the second stage is 2013-2017 years.

In the first stage, the keywords of the research on CSR in China are stakeholders, harmonious society, information disclosure, financial performance, and social responsibility report. This phenomenon is mainly derived from the establishment of the concept of social responsibility in modern enterprises. In order to achieve the purpose of improving financial performance, enterprises have gradually changed to satisfy the interest demands of stakeholders instead of passively bear economic responsibility and legal responsibility. At the same time, this phenomenon is also influenced by the "social responsibility management system of Chinese textile enterprises" published in 2005 and "the guidance of social responsibility of listed companies" issued by the 2006 Shenzhen Stock Exchange. Most of these documents suggest that the company should take responsibility for its stakeholders, the environment, the state and the society, and encourage the public companies to establish a social responsibility disclosure system. From 2013 to 2017, the research on political connection, institutional environment, institutional pressure, property right nature and earnings management has gradually become a new research hotspot. This stage is mainly influenced by China's transition period, and the relationship occupies a dominant position in the social structure. Because the government has the core resources that the enterprise must depend on, the enterprise will invest some resources in the system environment and fit in with it (fulfill the corporate social responsibility, etc.) to get the government's support. At the same time, the different property rights of state-owned enterprises and private enterprises will also affect their political relations. The state-owned listed companies can obtain more long-term debt financing and financial subsidies than private listed companies [5]. In a comprehensive view, the focus of research in the field of corporate social responsibility is changing, and it is gradually changing from whether the enterprise should fulfill the social responsibility to how to better and more accurately perform the social responsibility, in order to achieve maximum good at the same time and avoid negative effects.

\subsubsection{Dynamic Analysis of Domestic CSR Research Frontier}

Research frontiers are defined as a new, transient concept and potential research questions [6]. Analyzing the research frontier of CSR can better grasp the development trend and future direction of CSR, and the keywords with higher frequency of mutation are suitable for research frontiers [7]. Therefore, in this paper, we use Burst Term to detect mutant words, select nodes with frequent Top $\mathrm{N}=50$, and slice them yearly. Finally get ten main mutational words, as shown, in Table 4. 
Table 4. The main mutational words obtained by Burst detection.

\begin{tabular}{|c|c|c|c|c|c|}
\hline No. & Mutational words & $\begin{array}{l}\text { Burst } \\
\text { strength }\end{array}$ & Beginning & Ending & 2008-2017 \\
\hline 1 & Harmonious society & 10.20 & 2008 & 2009 & \\
\hline 2 & Financial performance & 7.72 & 2009 & 2013 & \\
\hline 3 & Political connection & 7.26 & 2014 & 2015 & \\
\hline 4 & Social responsibility information & 6.83 & 2008 & 2011 & \\
\hline 5 & $\begin{array}{l}\text { Social responsibility } \\
\text { information disclosure }\end{array}$ & 6.54 & 2012 & 2016 & \\
\hline 6 & Property rights & 6.35 & 2015 & 2016 & \\
\hline 7 & Financial crisis & 5.69 & 2009 & 2009 & \\
\hline 8 & Stakeholder theory & 5.27 & 2008 & 2010 & \\
\hline 9 & Business ethics & 5.16 & 2008 & 2010 & \\
\hline 10 & Corporate reputation & 5.10 & 2010 & 2014 & \\
\hline
\end{tabular}

From Table 4, we can see that the 10 mutational words are harmonious society, financial performance, political connection, social responsibility information, social responsibility information disclosure, property rights, financial crisis stakeholder theory, business ethics and corporate reputation. Among them, financial performance, social responsibility information and corporate reputation are relatively early and long lasting. They constitute an important part of the preliminary research on CSR of domestic enterprises in the past ten years. The political connection, social responsibility information disclosure and property right nature not only have a higher Burst intensity, but also the mutation time is generally late. They are the research topic of domestic corporate social responsibility research.

\subsubsection{Main Research Hot Spots and Frontier Analysis}

On the basis of keyword cluster analysis, time zone analysis and Burst detection, the main research hot spots and frontiers in the field of domestic corporate social responsibility can be summarized as four aspects: stakeholder, financial performance, political connection and social responsibility information disclosure. Around these four aspects, domestic scholars have carried out a lot of research and achieved fruitful research results.

\section{1) Stakeholder}

Since 1984 Freeman defines stakeholders as "all the individuals and groups that can affect an organization's goals or are affected by an organizational goal [8]", more and more researchers are studying corporate social responsibility 
from the perspective of stakeholders. The domestic research is divided into three categories:

First, some scholars define corporate social responsibility from the perspective of stakeholders. Qu Xiaohua thinks that corporate social responsibility refers to all kinds of positive obligations and responsibilities of enterprises, which are performed by employees, business partners, customers (consumers), communities and countries through enterprise system and enterprise behavior. It is a kind of positive reaction to the market and the group of related interests, and also a comprehensive indicator of enterprise management goals [9]. Zhang Zhaoguo, etc. defines corporate social responsibility as an enterprise based on a set of institutional arrangements (including formal and informal systems), liability for other stakeholders, such as creditors, governments, suppliers, customers, employees and communities, as well as the environment (legally or morally) while undertaking economic responsibility for shareholders [10].

Second is to explore the dynamic mechanism of corporate social responsibility from the perspective of stakeholders. Pressure from stakeholders and institutional pressure will encourage enterprises to undertake social responsibility passively [11]. At the same time, for the reason that enterprises can create value for themselves by assuming social responsibility, they will also take the initiative to fulfill their responsibilities to different stakeholders. For example, corporate accountability to employees and customers can significantly improve employee task performance and reduce employee turnover, thereby increasing value [12]; enterprises fulfilling their responsibilities to suppliers can reduce procurement costs, ensure procurement quality and delivery timeliness, thereby reducing operational risks and creating value for enterprises [13]; enterprises bear the responsibility to the government can reduce the cost of illegal activities, foster a good external environment, thereby reducing operational risks and creating value for enterprises [14].

The three is to explain how an enterprise should undertake social responsibility from the perspective of stakeholders. Zhang Zhaoguo believes that with the development of corporate social responsibility, strategic management of enterprises should be transformed from strategic management based on "shareholders first" into strategic management based on social responsibility [10]. It will help to match the social responsibility activities of enterprises with the core strategy of enterprises, so as to create value for society and economic value for themselves. By comparing the characteristics of the social responsibility behavior of different types of enterprises, Gui Wenjuan believes that the integration of CSR and the core strategy of the enterprise can promote the enterprise to identify the opportunities, focus on the investment innovation and the long-term competitiveness, and create the shared value of the enterprise and the society [15].

\section{2) Financial performance}

In recent years, because corporate behavior ultimately reflects corporate fi- 
nancial performance, more and more scholars have begun to study the relationship between corporate social responsibility and financial performance. However, no matter whether they are domestic scholars or foreign scholars, there has not been a unified conclusion. The research results of the past domestic literatures can be roughly divided into the following three aspects:

One is positive correlation. At present, in the research results of the relationship between corporate social responsibility and financial performance, it is common that the corporate performance of social responsibility will have a positive impact on its financial performance. Qiao Haishu and Tian Hong respectively confirmed that financial enterprises and communication enterprises can improve their financial performance by fulfilling their social responsibilities [16] [17]. In addition, there are also studies showing that there is interaction between them, not only Enterprise fulfilling social responsibility will positively affect the financial performance, but also the financial performance has a positive impact on Enterprise fulfilling social responsibility. For example, the findings of Yang Yi and Shen Hongtao showed that the social responsibility and financial performance of our company were mutually beneficial, influenced each other and promoted each other [18], and Wang Wencheng and Wang Shihui made similar conclusions in the 2014 study [19].

Two is the negative correlation. When most research results show that there is a positive correlation between corporate social responsibility and financial performance, some results show that there is a negative correlation between the two. The results of Li's study in 2006 show that the more corporate social responsibility is in the current period, the lower the value of the enterprise, the profitability of the ST companies in the previous year of the financial situation or other abnormal conditions are significantly negatively related to the corporate social responsibility [20]. There are also studies showing that the relationship between corporate social responsibility and financial performance will be affected by the period, although the impact of corporate social responsibility on the current financial performance is negative, but in the long run, the corporate performance of social responsibility has a positive impact on its financial performance [21].

Three is not related. In addition to the above two relationships, some results show that there is an unrelated relationship between corporate performance of social responsibility and corporate financial performance, that is, the performance of corporate social responsibility will neither improve nor reduce the financial performance of the enterprise. On the basis of the integration of social capital theory, Shi Junwei has carried out an empirical test on the survey data of 151 Chinese enterprises. The results show that there is no correlation between corporate social responsibility and economic performance [22]. Chen Xujiang based on stakeholder theory examines the impact of social responsibility on financial performance in China's state-owned and private listed companies. The results show that the comprehensive social responsibility has no significant im- 
pact on financial performance (accounting performance and market performance) [23].

\section{3) Political connection}

The so-called political connection means that the enterprise establishes a good relationship with the government through various ways [24], and the political connection is different from the political intervention and corruption and bribery. It is legal on the legal level and can bring such positive effects as financing convenience, preferential tax rate and government assistance to enterprises under the backwardness of the system. But at the same time, it may bring negative effects to the whole society, such as distorting market resource allocation mechanism and increasing official corruption [25]. Because our country is still in the transition period, the market economy system is not perfect, the government has the core resources that the enterprise must depend on, so the enterprise will invest some resources in the system environment and fit in with it (fulfill the corporate social responsibility) to get the support of the government. From the perspective of the strategic use of social responsibility of private enterprises, $\mathrm{Li}$ Shu has proved that the implementation of corporate social responsibility can help enterprises establish political connections [26]. But at present, more research in China takes the political connection as a predominant factor to analyze the relationship with the enterprise to fulfill the social responsibility. Zhang Ping and Liang Bo take the data of Chinese private enterprises as samples to confirm that the political connections of private enterprises are positively related to the fulfillment of social responsibilities. The higher the level of political connections is, the better the performance of social responsibilities [27]. Zhang Chuan et al. divided the political connection into two types of representative members and government officials. The empirical results show that the political relevance of the representative committee has a significant positive impact on corporate social responsibility. The higher the level of political connection is, the better the corporate social responsibility is, but the impact of government officials' political connections on corporate social responsibility is not significant [24].

\section{4) Information disclosure of social responsibility}

Since the self-regulation department issued a series of policies that require related companies to disclose corporate social responsibility information, the number of corporate disclosure of social responsibility reports has increased rapidly from 371 in 2008 to 1710 in 2016 . However, according to the relevant statistical analysis, not only the overall level of social responsibility information disclosure of Listed Companies in China is poor, but in the 2700 listed companies, the insufficient $1 / 3$ of the social responsibility report is published every year, and the quality of disclosure is also quite different, which provides rich material for the research of the academia. At present, domestic researches on corporate social responsibility information disclosure mainly focus on two aspects: 
The first is to study the motivation of corporate social responsibility information disclosure. The research on this aspect is mainly carried out from the institutional environment, the nature of the enterprise and the characteristics of the executives. For example, Yang Hanming and $\mathrm{Wu}$ Danhong starting with the system theory confirmed that the institutional environment of government institutions, industry associations and news media will form institutional pressure on the enterprise, and then through the characteristics of the company to influence the disclosure of social responsibility information [28]. With the sample of 2007-2009 years listed companies in Shenzhen and Shanghai, Feng Lili et al. found that the ownership concentration of the state-owned listed companies has a significant positive correlation with the performance of social responsibility. The concentration degree of non state-owned listed companies has no significant influence on the performance of social responsibility [29]. Zhang Zhengyong and Geely used 1207 social responsibility reports from a share listed companies in 2008-2010 years as samples. The empirical results show that there is a significant positive relationship between entrepreneurs' educational background, age, social reputation and the level of corporate social responsibility information disclosure [30].

The two is to study the value of corporate social responsibility information disclosure. This study focuses on the disclosure of social responsibility information can reduce information asymmetry, which will bring benefits such as reducing capital costs, alleviating financing constraints and improving financial performance. On the basis of information asymmetry, Meng Xiaojun studies the relationship between corporate social responsibility information disclosure and capital cost. The results show that voluntary disclosure of social responsibility information helps to increase information transparency, reduce information asymmetry and reduce capital cost [31]. He Xianjie and other research results on the related data of corporate social responsibility report of Listed Companies in China show that corporate social responsibility information disclosure can reduce the information asymmetry of enterprises, and then alleviate the degree of corporate financing constraints [32].

\subsection{Summary}

Through the analysis of the research power of CSR in China, it is found that there is cooperation between scholars and institutions, but the intensity is not enough, it has affected the research progress of domestic corporate social responsibility to a certain extent. The main research hotspots in the field of corporate social responsibility in China can be summarized as stakeholders, financial performance, political connections and disclosure of social responsibility information. They also represent the future research direction.

\section{Conclusions}

This paper took 3873 articles in the field of corporate social responsibility, which 
are included in the 2008-2017 years of CNKI as the object of study, using the latest version of Citespace software to quantitative analysis the literature samples, and then using the knowledge map to show the key words in the field of social responsibility in domestic enterprises, as well as some important academic researchers and academic institutions, which aims to reveal the hot research and frontier trends in the field of social responsibility of domestic enterprises.

First of all, through the analysis of the research force of domestic corporate social responsibility, we find that the current status of the main research forces is not conducive to the progress of domestic enterprise social responsibility research. From the core of the document, Renmin University of China Business School has the highest number of documents. The following is the school of economics and management, Shanghai Jiao Tong University, the Zhongnan University of Economics and Law Accounting School, the Huazhong University of Science and Technology School of Management and the Jinan University Management School. They constitute a representative research institution in the field of domestic corporate social responsibility. From the core authors, Tian Hong, Zhou Zucheng, Xin Jie and Xiao Hongjun have great influence on this field. However, both the core organization analysis and the core author analysis show that the structure of the author's network is fragmentary, and has not formed a certain scale. The relationship is not close enough, and the degree of cooperation is low, which restrict the research progress of the domestic enterprise social responsibility to a certain extent. Therefore, the future should break through the obstacles of cooperation between the authors and institutions, strengthen the relationship between the authors and institutions, and constantly improve the cooperation mechanism, striving to form a network structure with close ties and high degree of cooperation in the field of corporate social responsibility, which is led by authoritative institutions and high level scholars.

Secondly, through the keyword LLR clustering, the hot evolution time zone map and the Burst detection and analysis, the hot and front of the domestic enterprise social responsibility research is clarified, which are mainly summarized as stakeholder, financial performance, political connection and social responsibility information disclosure. In the stakeholders, domestic research mainly defines corporate social responsibility from the perspective of stakeholders, discusses the dynamic mechanism of corporate social responsibility, and explains how the enterprise should bear social responsibility. In terms of financial performance, domestic research mainly studies the relationship between financial performance and corporate social responsibility, which is mainly divided into three types: positive correlation, negative correlation and non correlation. In the political connection, the domestic research is mainly to analyze it as a predominant factor, which is also related to the social development stage of our country. In the aspect of social responsibility information disclosure, domestic research is mainly carried out from the motivation of corporate disclosure of social respon- 
sibility information and the value it can bring.

\section{Conflicts of Interest}

The authors declare no conflicts of interest regarding the publication of this paper.

\section{References}

[1] Davis, K. (1960) Can Business Afford to Ignore Social Responsibilities? California Management Review, 2, 70-76. https://doi.org/10.2307/41166246

[2] You, L. and Wang, J.S. (1990) On Corporate Social Responsibility. Journal of Sichuan University: Philosophy and Social Sciences, No. 1, 41-46.

[3] Zhang, Y.H. and Liu, M.Y. (2016) Visual Analysis of Sports Industry Research in China Based on Knowledge Map. China Sports Science and Technology, 52, $24-29+35$.

[4] Hu, C.Y., Liu, B.L. and Liao, X.L. (2017) Research Hot Spots and Frontiers of China's Regional Coordinated Development Policy - Analysis of Visual Mapping Knowledge Domain Based on Cite Space. Journal of South China Normal University (Social Science Edition), No. 5, 98-109+191.

[5] Jiang, W. and Li, B. (2006) Institutional Environment, State-Owned Property Rights and Bank Differential Loans. Finance Research, No. 11, 116-126.

[6] Chen, C. (2006) CiteSpace II: Detecting and Visualizing Emerging Trends and Transient Patterns in Scientific Literature. Journal of the Association for Information Science \& Technology, 57, 359-377. https://doi.org/10.1002/asi.20317

[7] Li, J. and Chen, C.M. (2016) CiteSpace: Technology Text Mining and Visualization. Capital University of Economics and Trade Press, Beijing, 193-206.

[8] Freeman, R. (1984) Strategic Management: A Stakeholder Perspective. Prentice Hall, Englewood Cliffs.

[9] Qu, X.H. (2003) An Interactive Study on the Evolution of Corporate Social Responsibility and Positive Corporate Behavior. Management Modernization, No. 5, 13-16.

[10] Zhang, Z.G., Liang, Z.G. and Yin, K.G. (2012) Research on CSR from the Perspective of Stakeholders. China Soft Science, No. 2, 139-146.

[11] Tian, H. and Jiang, Y.F. (2014) Research on the Dynamic Mechanism of Corporate Social Responsibility Performance. Audit and Economic Research, 29, 65-74.

[12] Li, X.J., Yang, D.N. and L.M. (2012) Cross-Layer Analysis of the Impact of CSR Behavior on Employee Performance. China Management Science, 20, 132-137.

[13] Zhang, L.X., Yuan, D.N., Niu, D. and Jin, Y. (2011) The Empirical Research on the Impact of Corporate Social Responsibility on Financial Performance Is the Research Object of Listed Companies in China. Journal of Northeastern University (Natural Science Edition), 32, 292-296.

[14] Wang, Q.G. and Xu, X.Y. (2016) The Value Creation Mechanism and Empirical Test of Corporate Social Responsibility-Based on Stakeholder Theory and Life Cycle Theory. China Soft Science, No. 2, 179-192.

[15] Zhu, W.J., Tan, J.S. and Zhang, H.Y. (2012) Review of Strategic Management Perspectives in Corporate Social Responsibility Behavior. Journal of Management, 9 , 345-355.

[16] Qiao, H. and Tan, M. (2009) Empirical Study on the Relationship between Financial 
Corporate Social Responsibility and Financial Performance. Financial Manager Theory and Practice, 30, 17-21.

[17] Tian, H. (2009) Correlation between CSR and Corporate Performance-Based on Empirical Data from China's Telecommunications Industry. Economic Management, No. 1, 72-79.

[18] Yang, Y. and Shen, H. (2008) Empirical Study on the Relationship between Corporate Social Responsibility and Financial Performance in China. Jinan Journal of Philosophy and Social Sciences, 30, 60-68.

[19] Wang, W. and Wang, S. (2014) A Study on the Correlation between Social Responsibility and Corporate Performance of State-Owned Enterprises in China. China Soft Science, No. 8, 131-137.

[20] Li, Z. (2006) A Study on the Correlation between Corporate Social Responsibility and Corporate Value-Empirical Evidence from Shanghai Listed Companies. China Industrial Economy, No. 2, 77-83.

[21] Wen, S. and Fang, Y. (2008) An Empirical Study on the Relationship between Corporate Social Responsibility and Financial Performance-Panel Data Analysis of Stakeholder Perspective. China Industrial Economy, No. 10, 150-160.

[22] Shi, J., Hu, L. and Fu, H.Y. (2009) Corporate Social Responsibility, Social Capital and Organizational Competitive Advantage: A Strategic Interaction Perspective-Empirical Research on China's Industrial Economy Based on the Experience of Transition Period. China Industrial Economics, No. 11, 87-98.

[23] Chen, Y. (2014) The Mediating Effect of Corporate Social Responsibility on Financial Performance-Empirical Evidence Based on the Social Responsibility Development Index of the Top 100 Enterprises in China. Journal of Shanxi University of Finance and Economics, No. 3, 12-13.

[24] Zhang, C., Lou, Z. and Jan, D. (2014) Political Connection, Financial Performance and Corporate Social Responsibility-Management Review from the Listed Companies of China's Chemical Industry. Business Review, 26, 130-139.

[25] Zhao, F. and Ma, G. (2011) Review and Prospect of the Study of Political Connections. Economic Review, No. 3, 151-160.

[26] Li, S. and Xie, X.Y. (2014) The Social Responsibility, Political Connection and Debt Financing of Private Enterprises-Empirical Evidence from China's Capital Market. South Open Management Review, 17, 30-40+95.

[27] Zhang, P. and Liang, B. (2012) Political Connections and Social Responsibility Performance-Evidence from China's Private Enterprises. Accounting and Economic Research, 26, 14-23.

[28] Yang, H. and Wu, D. (2015) Institutional Motivation and Path Selection of Corporate Social Responsibility Information Disclosure: An Analytical Framework Based on "Institutional Identity". Journal of Zhongnan University of Economics and Law, No. 1, 55-62+159.

[29] Feng, L., Lin, F. and Xu, J. (2011) Property Rights, Ownership Concentration and Corporate Social Responsibility Performance. Journal of Shanxi University of Finance and Economics, 33, 100-107.

[30] Zhang, Z. and Zhang, Z.G. (2013) The Entrepreneurial Population Background Features and Social Responsibility Information Disclosure-Empirical Evidence from the Social Responsibility Report of Chinese Listed Companies. China Population, Resources and Environment, 23, 131-138.

[31] Meng, X., Shaw, P.P. and Qu, J. (2010) The Interactive Relationship between Cor- 
porate Social Responsibility Information Disclosure and Capital Cost-An Analytical Framework Based on the Information Asymmetry Perspective. Accounting Research, No. 9, 25-29+96.

[32] He, X., Xiao, T. and Chen, X. (2012) Corporate Social Responsibility Information Disclosure and Corporate Finance Constraints. Financial Research, 38, 60-71+83. 